\title{
Comprehensive investigation of low-salinity waterflooding in sandstone reservoirs
}

\author{
M. Fouad Snosy ${ }^{1} \cdot$ Mahmoud Abu El Ela ${ }^{2} \cdot$ Ahmed El-Banbi $^{3} \cdot$ Helmy Sayyouh ${ }^{2}$
}

Received: 7 December 2019 / Accepted: 17 February 2020 / Published online: 24 February 2020

(c) The Author(s) 2020

\begin{abstract}
Waterflooding has been applied for many years as secondary recovery method with no or little regard to the effect of the injected water salinity on oil recovery. However, in the last decade, there has been an increasing interest in understanding the effects of changing injected water salinity on reservoir performance. The potential of low-salinity waterflooding (LSWF) has been studied in sandstone reservoirs by numerous core-flooding experiments. These experiments have shown diverse results. This paper aims to investigate the effects of changing water salinity on oil recovery. A comprehensive review and analysis of the results of more than 500 core-flood experiments from published work were investigated to study the effects of several parameters such as clay content, clay type, and temperature on oil recovery. The relation between incremental oil recovery and sodium adsorption ratio SAR, and exchangeable sodium percentage (ESP) parameters which control clay swelling was illustrated. The analysis of the results revealed that there is an optimum composition and optimum salinity for waterflooding in secondary flooding stage. However, for tertiary flooding stage, the results showed that the controlling factor may be not decreasing the salinity but rather changing the salinity (e.g., either increasing or decreasing) with minor improvement in oil recovery. It was clear also that applying the optimum salinity in the secondary recovery stage is more effective than applying it in the tertiary recovery stage. This study aims to develop important guidelines for screening and designing optimum salinity for waterflooding projects in sandstone reservoirs.
\end{abstract}

Keywords Low-salinity waterflooding $\cdot$ Smart waterflooding $\cdot$ Enhanced oil recovery

\begin{tabular}{ll}
\multicolumn{2}{l}{ Abbreviations } \\
EDL & Expansion of double layer \\
EOR & Enhanced oil recovery \\
ESP & Exchangeable sodium percentage \\
Fm & Formation water \\
HS & High-salinity water \\
IFT & Interfacial tension \\
$\mathrm{K}_{\mathrm{o}}$ & Oil permeability \\
$\mathrm{K}_{\mathrm{w}}$ & Water permeability \\
LS & Low-salinity water \\
LSWF & Low-salinity waterflooding \\
MIE & Multi-component ion exchange \\
NMR & Nuclear magnetic resonance \\
OOIP & Original oil in place
\end{tabular}

M. Fouad Snosy

mfsnosy@yahoo.com

General Petroleum Company, Cairo, Egypt

2 Cairo University, Giza, Egypt

3 American University in Cairo, New Cairo, Egypt
SAR Sodium adsorption ratio

TDS Total dissolved salts

XRD X-ray powder diffraction

\section{Introduction}

Bernard (1967) reported the first effect of applying lowsalinity waterflooding. Later, numerous experiments have been conducted to study the effect of LSWF on oil recovery. Tang and Morrow (1997) showed that the oil recovery increased about $20 \%$ due to applying low-salinity water. Vledder et al. (2010) stated that the application of LSWF was economic for new fields. Webb et al. (2004) showed an increase in oil recovery due to reduction in the injected brine salinity from 80,000 to $30,000 \mathrm{ppm}$ and then a significant increase after reducing it to $1000 \mathrm{ppm}$.

Alotaibi et al. (2010) observed completely opposite results after studying oil/water/rock interactions at different salinities and elevated temperature conditions on outcrops using synthetic formation brines, aquifer, and 
seawater under high-pressure conditions. They observed direct relationship between zeta potential and ionic strength. Patil et al. (2008) observed reduction in the residual oil saturation up to $20 \%$ and slight increase in the Amott-Harvey wettability index due to the decrease in the salinity on ten core plugs from Alaska North Slope field using three different water salinities $(22,000,11,000$, and 5500 ppm TDS).

It should be highlighted that there is very limited published information on the low-salinity waterflooding pilot tests. Zeinijahromi et al. (2015) described a 7-year lowsalinity water injection project comprising of eight injectors and 29 producers in Zichebashskoe field. He built numerical model (using fines migration concept) and compared the results of the model with the conventional waterflooding. He showed that low-salinity water injection resulted in less than $0.1 \%$ improvement in the incremental oil recovery compared with waterflooding using formation water. He explained that the failure reasons are due to applying low-salinity waterflooding after flooding by high-salinity water.

BP predicted the incremental oil recovery from tertiary LSWF in BP's offshore Endicott field to be in the range of $6-12 \%$ from the original oil in place (OOIP). The saturation change was measured using single well reactive chemical tracer tests (SWCTTs) in four wells. However, Shell applied the LSWF with 500 ppm in Omar oil field in Syria due to operational requirements. The analysis indicated that there was a decrease in the wettability from the original, which may be responsible for an expected incremental recovery of about $5-15 \%$ from the OOIP (Law et al. 2014).

Although the main mechanism for low salinity is still debatable, the proposed mechanisms are fines migration, surface roughening due to clay swelling, osmosis pressure effects, pH effects, salting in, multi-component ion exchange (MIE), double-layer effects, and the low-salinity chemical mechanism proposed by Austad et al. (2010).

Fines migration was suggested initially by Bernard (1967) and was accepted by Tang and Morrow (1999), Skauge et al. (2008), and Hadia et al. (2012). This suggestion was not agreed upon by Pu et al. (2008), Cissokho et al. (2010), Zhang et al. (2007), Lager et al. (2008a), Jerauld et al. (2006), Rivet et al. (2010), Shaker and Skauge (2013), and Amirian et al. (2017) who noticed an increase in the oil recovery without fines migration.

The increase in the water $\mathrm{pH}$ was expected due to adsorption/desorption of carboxylic material onto clay by Morrow et al. (1998) and McGuire et al. (2005) and was accepted by Piñerez et al. (2016). However, no direct relationship between $\mathrm{pH}$ and increased oil recovery was noticed by Lager et al. (2008b) and Rezaeidoust et al. (2009).
Surface roughening due to clay swelling was proposed by Marhaendrajana et al. (2018). He showed that the increase in surface roughness due to clays swelling modifies the surface water wetness. He also clarified that the determination of the clay swelling threshold is essential to minimize the effect of pore blocking.

Sandengen and Arntzen (2013) suggested that the increase in the osmotic pressure causes brine expansion and oil displacement. This mechanism was agreed by Sandengen et al. (2016), Fredriksen et al. (2016), and Fredriksen et al. (2017). However, Bartels et al. (2017) showed that the osmosis pressure can contribute in the incremental oil recovery, but it is not the primary mechanism of LSWF.

Salting in was predicted by Austad et al. (2010) and Rezaeidoust et al. (2009), due to an increase in the solubility of organic polar components in the aqueous phase. However, this mechanism was refused by Austad et al. (2010) as he did not observe any significant difference between the salinity conditions in the desorption process.

Multi-component ion exchange (MIE) evidence was proposed by Sposito (1989) and was accepted by Buckley et al. (1998), Seccombe et al. (2008), Lager et al. (2008a), Rezaeidoust et al. (2010), Mugele et al. (2016), and Arumugam et al. (2019). This suggestion was contradicted by Cissokho et al. (2010) and Austad et al. (2010) who performed lowsalinity floods containing no divalent ions which resulted in increased oil recovery.

Double-layer effects were proposed by Ligthelm et al. (2009) who showed that a decrease in the water salinity will increase the thickness of the ionic double layer between the clay and oil interfaces which decreases the electrostatic repulsion force and increases the mineral surface zeta potential. Thus, a release of the organic material and wettability alteration can be achieved when injection of low-salinity brine is performed. Austad et al. (2010) showed that the double-layer effect is explained by the bridging of $\mathrm{Ca}^{2+}$ between the clay and oil, which both have negatively charged interfaces. However, it is not necessary with a bridge of divalent cations, since polar oil components can adsorb onto clay minerals without a bridge of divalent cations. Haagh et al. (2017) showed that double-layer expansion (DLE) is essential for LSWF effect, but it is not the reason behind wettability alteration.

The chemical low-salinity mechanism was proposed by Austad et al. (2010). He showed that both basic and acidic organic materials are adsorbed onto the clay together with inorganic ions, especially $\mathrm{Ca}^{2+}$. Low-salinity waterflooding causes increase in the $\mathrm{pH}$ and causes desorption of ions with some of the adsorbed organic matter. He showed that the cation exchange capacity of the clay, which is in the order kaolinite $<$ illite mica chlorite $<$ montmorillonite, is essential for low-salinity effects. 
There are three mechanisms commonly referred in the literature: double-layer expansion (DLE), multi-component ion exchange (MIE) and the chemical mechanism. However, surface roughening and osmosis mechanisms are still under investigation.

The above introduction shows that increase in oil recovery from low-salinity water injection is possible and can be explained by numerous mechanisms. However, there is no agreement on which mechanisms are important and can act under which conditions. This observation opens the door to optimization of salinity and composition of water for achieving higher recovery for different types of rocks. The work is a trial to analyze the results of several core-flood experiments from the literature in order to have guidelines to improve oil recovery in typical waterfloods by changing/ optimizing water salinity and composition.

\section{Database of previous flooding experiments}

A database with results of more than 500 core-flood experiments was collected from the literature and used to provide additional insights in low-salinity waterflooding. Eighty plugs with more than 180 tertiary low-salinity waterflooding experimental runs and 75 plugs with more than 160 secondary waterflooding experimental runs are used in this analysis. (Twin plugs are considered as one plug.)

Table 1 and Fig. 1a, b show the histograms of the rock properties (porosity, permeability, and pore volume) of the 155 core plugs. The dataset covers range of the porosity from 5 up to $35 \%$. More than $75 \%$ of the data has a porosity range of $15-25 \%$. The maximum permeability recorded in the dataset was $4800 \mathrm{mD}$, while the minimum permeability was $5 \mathrm{mD}$. More than $35 \%$ of the data has a permeability range of $50-100 \mathrm{mD}$. From 155 plugs of dataset, only $42 \%$

Table 1 Summary of core-flood experiments results collected from the literature

\begin{tabular}{|c|c|c|c|c|c|c|c|c|c|}
\hline References & Type & No. of plugs & $\mathrm{PV}(\mathrm{cc})$ & Clay $(\%)$ & Por. $(\%)$ & Perm $(\mathrm{mD})$ & Kaol. & Albite & $\begin{array}{l}\text { Incr. oil } \\
\text { recovery, \% } \\
\text { OOIP }\end{array}$ \\
\hline \multirow[t]{2}{*}{ Agbalaka et al. (2008) } & Sec. & 27 & $4-5$ & NA & $16-30$ & $1-212$ & NA & NA & $6-20$ \\
\hline & Ter. & 6 & $4-5$ & & & & & & $2-20$ \\
\hline Pu et al. (2010) & Ter. & 7 & $7-16$ & NA & $10-19$ & $7-300$ & NA & NA & $0-8$ \\
\hline Hadia et al. (2011) & Ter. & 13 & $11-25$ & $3-7$ & $12-25$ & $11-4800$ & $1.5-6$ & 0 & $0-15$ \\
\hline Rezaeidoust et al. (2009) & Ter. & 7 & NA & $7-16$ & NA & $3-17.5$ & 3.5 & 0 & $0-6$ \\
\hline \multirow[t]{2}{*}{ Mjøs (2014) } & Sec. & Twin & $15-19$ & NA & $21-25$ & NA & NA & NA & 0 \\
\hline & Ter. & 6 & & & & & & & $0-5$ \\
\hline Zekri et al. (2011) & Sec. & 5 & NA & NA & $9-18$ & $2-162$ & NA & NA & $0-10$ \\
\hline \multirow[t]{2}{*}{ Shehata and Nasr-El-Din (2014) } & Sec. & Tw & $27-110$ & $6-22$ & $18-20$ & NA & $2-6$ & 0 & $4-16$ \\
\hline & Ter. & 8 & & & & & & & $0-7$ \\
\hline AlQuraishi et al. (2015) & Ter. & 3 & 45 & NA & 22 & $77-314$ & NA & NA & $1-10$ \\
\hline \multirow[t]{2}{*}{ Nasralla et al. (2011) } & Ter. & $25-31$ & 11 & 18 & $66-95$ & 5 & 0 & $25-31$ & 0 \\
\hline & $\mathrm{Sec}$ & $8 \mathrm{Tw}$ & $25-31$ & 11 & $18-19$ & $66-95$ & 5 & 0 & 20 \\
\hline Ashraf et al. (2010) & Sec. & $12 \mathrm{Tw}$ & NA & NA & $18-19$ & $76-183$ & NA & NA & $4-11$ \\
\hline \multirow[t]{2}{*}{ Piñerez et al. (2016) } & Ter. & 2 & $22-23$ & 43 & 20 & $22-48$ & 0 & 32 & $5-9$ \\
\hline & Sec. & $2 \mathrm{Tw}$ & & & & & & & 10 \\
\hline Hosseinzade et al. (2016) & Sec. & $2 \mathrm{Tw}$ & 113 & 8 & 15 & 270 & 0 & 1 & 10 \\
\hline Nasralla and Nasr-El-Din (2011) & Sec. & $13 \mathrm{Tw}$ & $30-32$ & 14 & $17-19$ & $88-137$ & 5 & 0 & $3-10$ \\
\hline Hadia et al. (2012) & Ter. & 4 & 15 & 19 & $14-15$ & $16-17$ & 6.5 & 6.5 & $0.1-3$ \\
\hline \multirow[t]{2}{*}{ Fjeldo et al. (2012) } & Ter. & 2 & 13 & 13 & 28 & 164 & NA & NA & 5 \\
\hline & Sec. & $2 \mathrm{Tw}$ & 12 & 13 & 27 & 99 & NA & NA & 7 \\
\hline \multirow[t]{2}{*}{ Nasralla and Nasr-El-Din (2012) } & Sec. & 4 & 106 & NA & 19 & $77-100$ & NA & NA & 10 \\
\hline & Ter. & 1 & & & & & & & 0 \\
\hline Alagic and Skauge (2010) & Sec. & $4 \mathrm{Tw}$ & 22 & NA & NA & 650 & NA & NA & 5 \\
\hline Shaker and Skauge (2012) & Ter. & 5 & 32 & & $19-25$ & $110-2200$ & NA & NA & $0-2$ \\
\hline Callegaro et al. (2013) & Ter. & 3 & $8-27$ & & $5-16$ & $0.5-273$ & 0 & 5 & $8-8.5$ \\
\hline Zeinijahromi and Bedrikovetsky (2013) & Sec. & 3 & 38 & NA & 19 & 90 & NA & NA & $8-12$ \\
\hline Siyambalagoda and Thyne (2011) & Ter. & 12 & $6-18$ & NA & $7-21$ & $4-267$ & NA & NA & $0-6$ \\
\hline Ramanathan et al. (2015) & Sec. & $4 \mathrm{Tw}$ & 406 & 13 & 18 & 78 & 6 & 3 & $(-6)-19$ \\
\hline
\end{tabular}



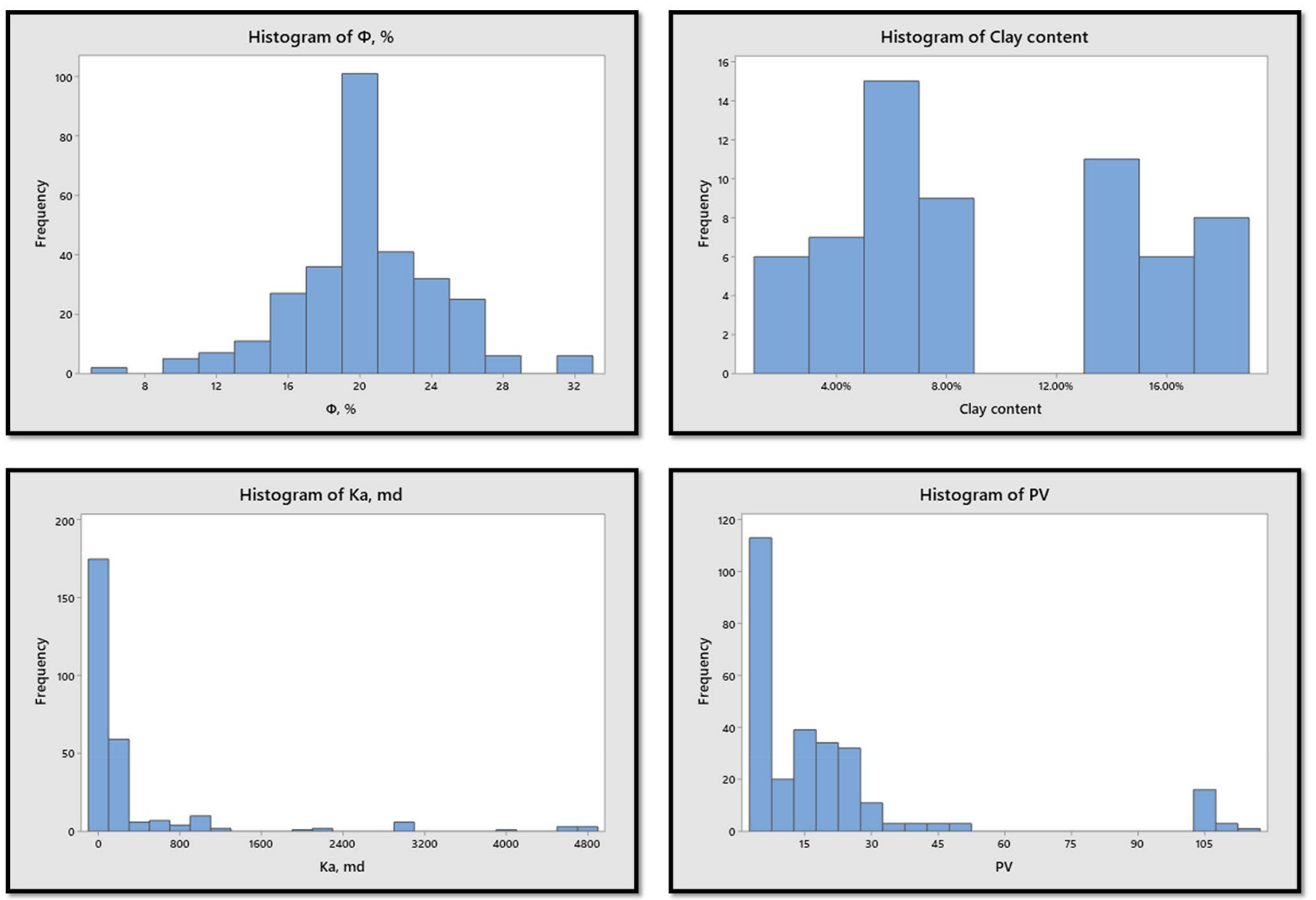

$\mathbf{a}$

b

Fig. 1 a Histograms of porosity and permeability of the plugs from the literature. b Histograms of clay content and pore volume of the plugs from the literature

of the plugs has a description of the clay content. More than $50 \%$ of data has clay content less than $10 \%$, while $5 \%$ of the data has more than $20 \mathrm{wt} \%$ clay content. More than $80 \%$ of the plugs had pore volume less than $30 \mathrm{~cm}^{3}$.

As shown in Table 1, the results from these waterflooding experimental runs indicated that the maximum additional oil recovery due to applying low-salinity waterflooding compared to high-salinity waterflooding in tertiary stage was about $15 \%$ of the OOIP, while the maximum additional oil recovery in secondary stage was about $20 \%$ of the OOIP. Figures $2 \mathrm{a}-\mathrm{d}$ and $3 \mathrm{a}-\mathrm{d}$ show the additional oil recovery versus permeability, clay content, kaolinite percentage, and low salinity (ppm) in the tertiary and secondary stages, respectively.

\section{Discussion}

\section{Analysis devices and test methods}

Table 2 presents the flooding devices and measurement methods which were used in the previous studies. Three methods have been used to conduct the flooding experiments in the secondary and tertiary stages. The first procedure was core flooding using liquid pump, piston cell, core holder, oven, glass beret, and computer-controlled system. The second procedure was the spontaneous imbibition method. In this method, the flooding was carried out by displacing the fluid with a pump in a sealed core holder. The volume of the displaced fluid could be measured directly or determined by weight measurements. The third procedure was carried out using micro-model. It was performed using micro-plugs, sand packs, or glass model with clay. Oil recovery was measured using micro-computer tomography (micro-CT).

Many methods were used to investigate the behavior of the wettability alteration due to the LSWF. The measurements were carried out using solid substrate. The contact angle was measured by drop shape technique using contact angle meter, digitizing camera, or scanning electron microscopy. Zeta potential is the potential difference between the dispersion medium and the stationary layer of fluid attached to the particle. It is measured by a zeta potential analyzer. The $\mathrm{pH}$ was measured using $\mathrm{pH}$ meter. However, the 


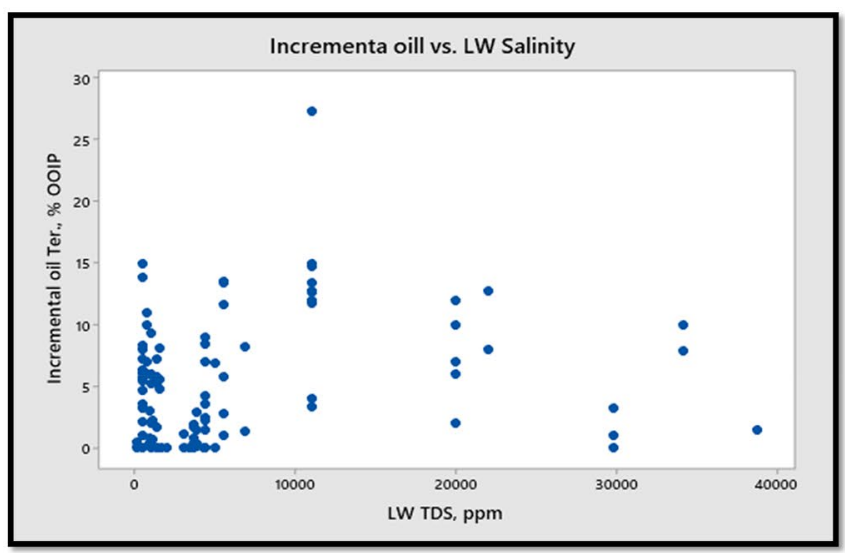

a

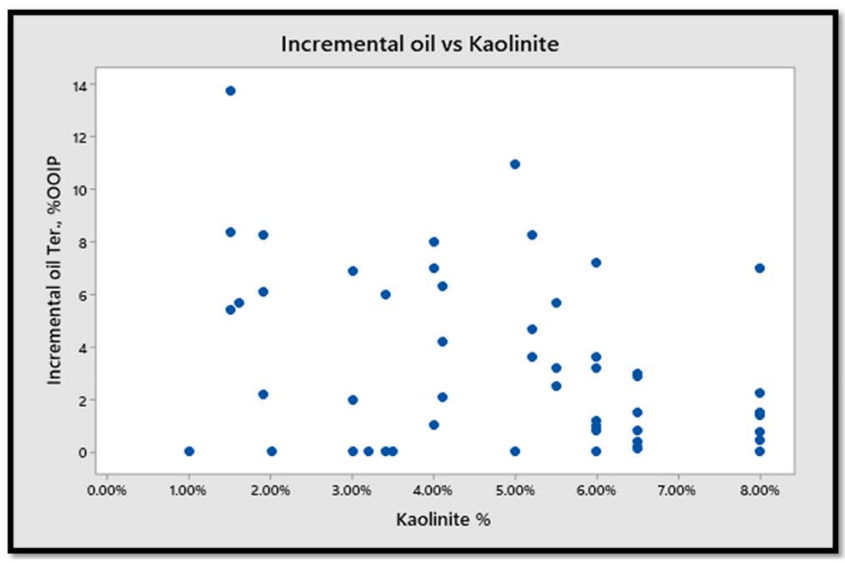

c

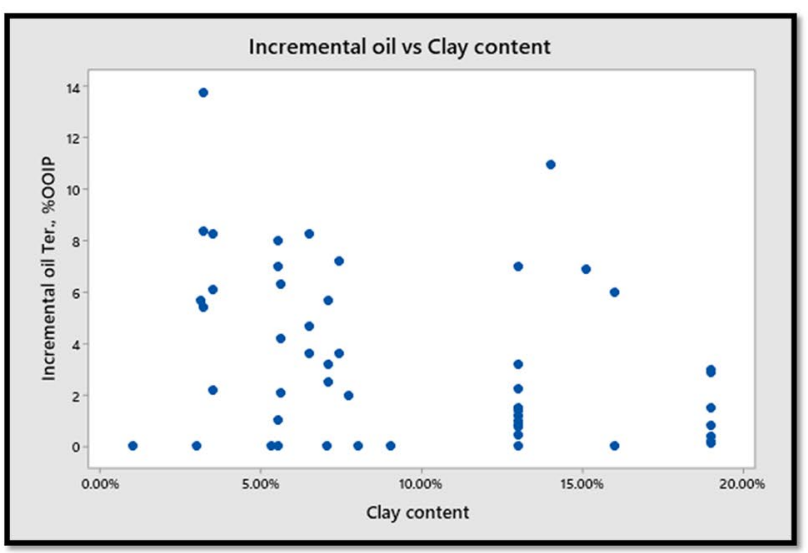

b

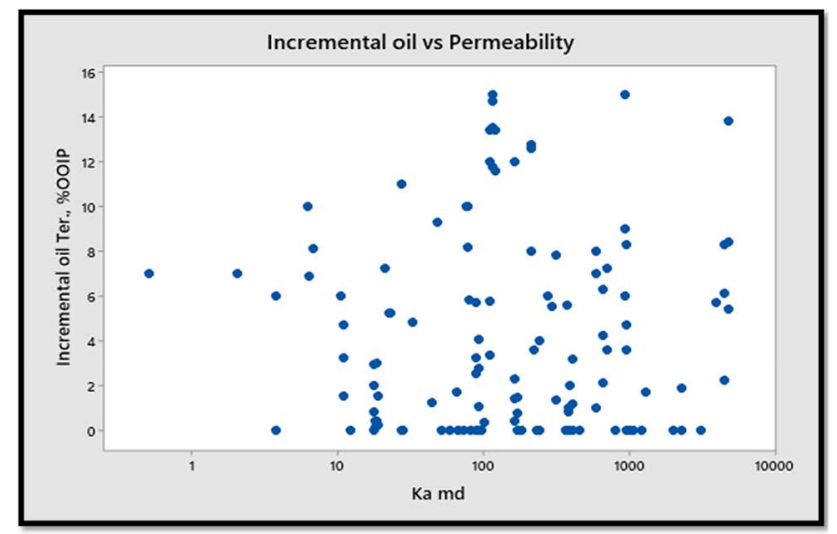

d

Fig. 2 a Tertiary incremental versus LW salinity of the literature data. b Tertiary incremental versus clay content of the literature data. $\mathbf{c}$ Tertiary incremental versus kaolinite of the literature data. $\mathbf{d}$ Tertiary incremental versus permeability of the literature data

interfacial tension was measured using tensiometer. Moreover, the wettability index was measured using Amott-Harvey method.

Bartels et al. (2017) used micro-model made of glass together with clay as a bulk of sandstone rock to study the effect of LSWF on the contact angle. He showed wettability modification as an effect of LSWF. However, Ashraf et al. (2010) performed core-flooding experiments for different wettability Berea cores at room conditions. The results showed increases in oil recovery as wettability changes from water- to neutral-wet conditions. Later, Shehata and NasrEl-Din (2015) performed spontaneous imbibition and coreflooding tests to study the effects of divalent cations during LSWF. The injected water with divalent cations gave oil recovery higher than the injected water without divalent cations. However, Fjelde et al. (2012) performed waterflooding using three different water salinities for sandstone plugs with high clay content. They documented that changing of wettability to become less water wet during injecting formation water and high-salinity water. Aghaeifar et al. (2015) carried out a set of core-flooding experiments at high temperatures,
Tres $>100{ }^{\circ} \mathrm{C}$, and at high $\mathrm{FW}$ salinities $~ 200,000 \mathrm{ppm}$. No incremental oil recovery was shown in this condition for LSWF. Shehata and Nasr-El-Din (2014) performed a set of core-flooding experiments in addition to measuring Zeta potential, X-ray powder diffraction XRD, $\mathrm{pH}$, and nuclear magnetic resonance (NMR). They concluded that the average pore throat radius affects significantly in LSWF during secondary stage.

\section{Salinity range for the LSWF applications}

Varying opinions exist in the literature regarding the optimum water salinity range that can improve oil recovery. One study proposed water salinity less than 6000 ppm to show additional recovery. The experimental work in this previous study indicated that the optimum salinity was between 1000 and 2000 ppm (Rotondi et al. 2014). In the work of Chavan et al. (2019) and Morrow and Buckley (2011), they recommended water salinity less than 5000 ppm in laboratory tests and less than $3000 \mathrm{ppm}$ in field tests to notice additional oil recovery. 


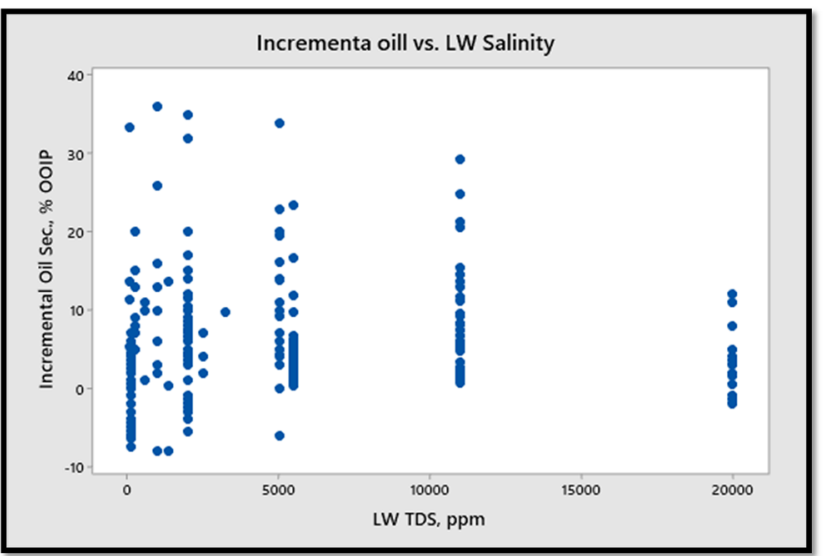

a

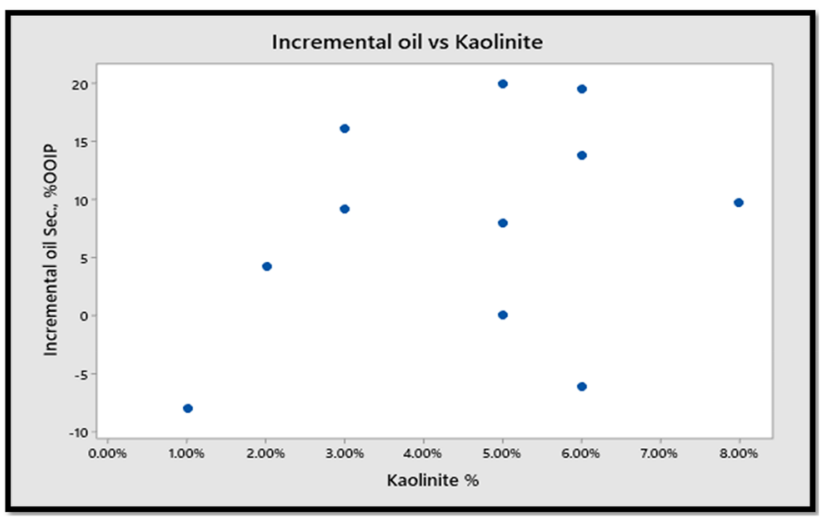

c

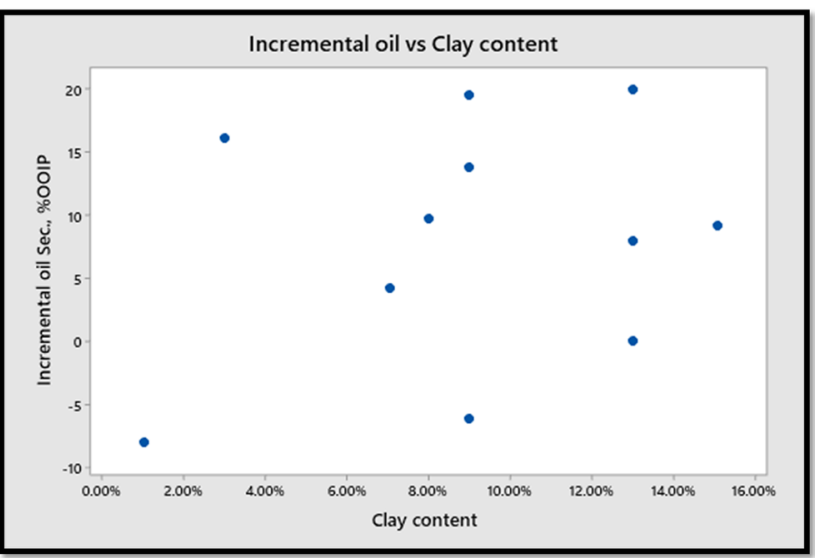

b

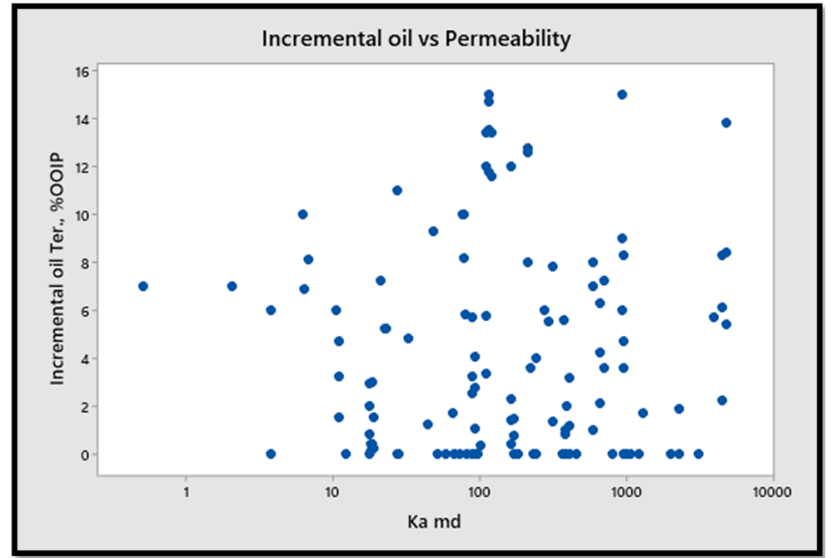

d

Fig. 3 a Secondary incremental versus LW salinity of the literature data. b Secondary incremental versus clay content of the literature data. c Secondary incremental versus kaolinite of the literature data. d Secondary incremental versus permeability of the literature data

However, the reviewed literature showed diverse results. Figure $2 \mathrm{a}$ shows the ranges of salinities with oil recovery in the tertiary stage. It is clear form Fig. 2a that the additional oil recovery was achieved using salinities up to $35,000 \mathrm{ppm}$. In addition, some experiments did not show any additional oil recovery even when using water salinities less than $5000 \mathrm{ppm}$. The maximum oil recovery due to applying LSWF in the tertiary stage was $15 \%$ at salinity less than 11,000 ppm as recognized by Hadia et al. (2011). The incremental oil recovery was less than $10 \%$ when applying LSWF of a salinity higher than 20,000 ppm.

Nasralla et al. (2011) and others concluded that low salinity in tertiary stage could be useless. Piñerez et al. (2016) showed that at least 2-8 PV is needed to notice improvement in oil recovery in the tertiary stage. Mjøs (2014) applied flooding with high water salinity after low water salinity and obtained additional recovery. The results reveal that changing salinity of injected water, either decreasing or increasing, may cause additional oil recovery in the tertiary stage.
Figure 3a shows additional oil recovery from WF in the secondary stage. High oil recovery was shown using salinities more than 10,000 ppm. The highest recorded incremental oil recovery was 33\% OOIP at salinity less than $100 \mathrm{ppm}$. The incremental oil recovery reached $30 \%$ when applying low salinity higher than 10,000 ppm. Moderate LSWF (average $3000 \mathrm{ppm}$ ) shows relatively better incremental recovery (up to $25 \%$ ).

Wei et al. (2017) and Mjøs (2014) showed lower recovery with ultra-low-salinity brine compared to low-salinity brine. Applying non-optimum water salinity even if it is LSWF can give less oil recovery.

Shehata and Nasr-El-Din (2014) and Fjelde et al. (2012) showed that applying optimum salinity gave less potential in the tertiary stage compared with applying it in the secondary stage in all plugs. In another study, Sandengen et al. (2011) showed insignificant incremental oil recovery in tertiary core floods after injecting of 2-3 first pore volumes. However, Piñerez et al. (2016) showed higher incremental oil recovery 
Table 2 Flooding devices and measurement methods of the previous experimental studies

\begin{tabular}{|c|c|c|c|c|c|c|c|c|c|}
\hline \multirow[t]{2}{*}{ Paper } & \multirow[t]{2}{*}{ Sample type } & \multicolumn{3}{|c|}{ Flooding devices } & \multicolumn{5}{|c|}{ Wettability indication methods } \\
\hline & & Core flooding & Micro-model & Imbibition & $\mathrm{pH}$ & IFT & Contact angle & Zeta potential & Others \\
\hline Piñerez et al. (2016) & Plugs & $\mathrm{V}$ & & & $\mathrm{V}$ & & & & \\
\hline Hosseinzade et al. (2016) & Micro-plug & & $\mathrm{V}$ & & & V & & & \\
\hline Shabaninejad et al. (2017) & Micro-plug & & V & & & & & & \\
\hline Keogh et al. (2017) & Sand packs & & V & & & & & & NMR \\
\hline Li et al. (2017) & Sand packs & $\mathrm{r}$ & & & & V & V & & \\
\hline Wei et al. (2017) & Plugs & & & & V & & & & \\
\hline Shaker and Skauge (2013) & Plugs & $\mathrm{V}$ & & & & & & & \\
\hline Mjøs (2014) & Plugs & r & & & & $\mathrm{V}$ & & & \\
\hline Agbalaka et al. (2008) & Plugs & V & & & & & & & \\
\hline Alagic and Skauge (2010) & Plugs & $\mathrm{V}$ & & & V & & & & \\
\hline Farooq et al. (2011) & Substrates & & & & & & $\mathrm{V}$ & & \\
\hline Fogden (2011) & Substrates & & & & V & & V & $\mathrm{V}$ & \\
\hline Hadia et al. (2012) & Plugs & $\mathrm{r}$ & & & $\mathrm{V}$ & & & & \\
\hline Zekri et al. (2012) & Plugs & V & & & & & V & & \\
\hline $\begin{array}{l}\text { Lebedeva and Fogden } \\
\text { (2011) }\end{array}$ & Sand packs & & & & & & V & $\mathrm{V}$ & \\
\hline Lu et al. (2017) & Substrates & & & & & & V & $\mathrm{V}$ & \\
\hline Navrátil (2012) & Plugs & V & & & V & & & & \\
\hline AlQuraishi et al. (2015) & Plugs & V & & & & V & V & V & \\
\hline Sandengen et al. (2011) & Plugs & V & & & V & & & & \\
\hline Alotaibi et al. (2010) & Substrates & & & & & V & V & V & \\
\hline Ashraf et al. (2010) & Plugs & V & & & & & & & Amott \\
\hline Austad et al. (2010) & Plugs & V & & & V & & & & \\
\hline Pu et al. (2010) & Plugs & V & & V & & & & & \\
\hline Facanha et al. (2017) & Substrates & & & & & & $\mathrm{V}$ & & \\
\hline $\begin{array}{l}\text { Shehata and Nasr-El-Din } \\
\text { (2014) }\end{array}$ & Plugs & r & & & & V & V & $\mathrm{V}$ & NMR \\
\hline $\begin{array}{l}\text { Shehata and Nasr-El-Din } \\
\text { (2017) }\end{array}$ & Plugs & r & & V & V & & & V & \\
\hline Fjelde et al. (2014) & Plugs & r & & & & & & & \\
\hline $\begin{array}{l}\text { Zeinijahromi and Bedriko- } \\
\text { vetsky (2013) }\end{array}$ & Plugs & r & & & & & & & \\
\hline Shaker and Skauge (2012) & Plugs & r & & V & & & & & Amott \\
\hline Callegaro et al. (2013) & Plugs & V & & & & & & & \\
\hline Mamonov et al. (2017) & Sand packs & & & V & & & & & \\
\hline $\begin{array}{l}\text { Nasralla and Nasr-El-Din } \\
\text { (2014) }\end{array}$ & Plugs & V & & & & & V & V & \\
\hline Mehana et al. (2017) & Plugs & & & V & & V & V & & \\
\hline Nasralla et al. (2011) & Plugs & r & & & & & & & \\
\hline Hadia et al. (2011) & Plugs & r & & & & & & & Amott \\
\hline Gamage et al. (2011) & Plugs & r & & & V & & & & \\
\hline Fjelde et al. (2012) & Plugs & $\mathrm{V}$ & & & V & & & & \\
\hline $\begin{array}{l}\text { Nasralla and Nasr-El-Din } \\
\text { (2011) }\end{array}$ & Plugs & V & & & & & & V & \\
\hline Miyauchi et al. (2017) & Plugs & V & & & V & & V & & \\
\hline RezaeiDoust et al. 2010 & Plugs & V & & & & & & & \\
\hline $\begin{array}{l}\text { Mohamed and Alvarado } \\
\text { (2017) }\end{array}$ & Plugs and substrates & & & V & & $\mathrm{V}$ & V & V & \\
\hline Kakati et al. (2017) & Substrates & & & & & V & V & & \\
\hline
\end{tabular}


with about $10 \%$ of the OOIP in the application of the LSWF in the secondary stage than those in the tertiary stage.

Fjelde et al. (2012) revealed that the repulsive force caused by LSWF in the tertiary stage is not enough to sweep trapped oil due to the absence of continuous oil film after injecting of high-salinity water. Furthermore, Sorop et al. (2013) showed that LSWF in secondary stage allows time for producing oil bank before the downfall of field life. In addition, changing of the formation fluids $\mathrm{pH}$ and salinity by injection of high water salinity decreases the effects of LSWF.

\section{Effect of water composition}

Robertson (2007), and Chavan et al. (2019) showed that there was an optimum composition of LSWF. However, limited information is available on how to determine the optimum salinity and composition for a particular rock. Hosseinzade et al. (2016) performed experiments by applying LSWF with the same salinity and different compositions. $\mathrm{He}$ observed that the LSWF with $\mathrm{Ca}^{2+} / \mathrm{Na}^{+}$ratio of 0.005 resulted in higher recovery than the one with $\mathrm{NaCl}$ only.

Nasralla and Nasr-El-Din (2011) reported that changing composition from $5000 \mathrm{CaCl}_{2}$ to $5000 \mathrm{NaCl}$ gave $7 \%$ more recovery, which means also that there is an optimum composition. They explained that LSWF with high concentration of $\mathrm{NaCl}$ might give higher oil recovery than with low concentration of $\mathrm{CaCl}_{2}$ or $\mathrm{MgCl}_{2}$. They showed that $\mathrm{NaCl}$ injection may not be strongly efficient with the formation brines containing high concentrations of divalent cations unless several pore volumes of $\mathrm{NaCl}$ are injected and dilution of the formation brine is achieved.

Haagh et al. (2017) showed a decrease in the contact angle on muscovite due to reduction in the divalent cation concentration to zero. In addition, negligible effect in the contact angle was noticed after decreasing ion strength without changing divalent ion concentration. Mugele et al. (2016) performed a series of experiments to study the effects of $\mathrm{pH}$ and ion content during LSWF. He showed that the salt content of injected water and concentrations of divalent ions have a strong effect on the wettability.

Tchistiakov (2000) attributes the effect of the LSWF to decreasing clay stability in the sandstone which forces the release of the monovalent cations from the clay surfaces to diffusion layers around the clay particles and changing the rock wettability.

Bourrie (2014) showed that sodium adsorption ratio (SAR) and exchangeable sodium percentage (ESP) are the key concept to explain swelling of clay minerals during irrigation.

The sodium adsorption ratio (SAR) is defined as: $\mathrm{SAR}=\mathrm{Na}^{+} / \sqrt{\left(\mathrm{Ca}^{+2}+\mathrm{Mg}^{+2}\right) / 2}$.

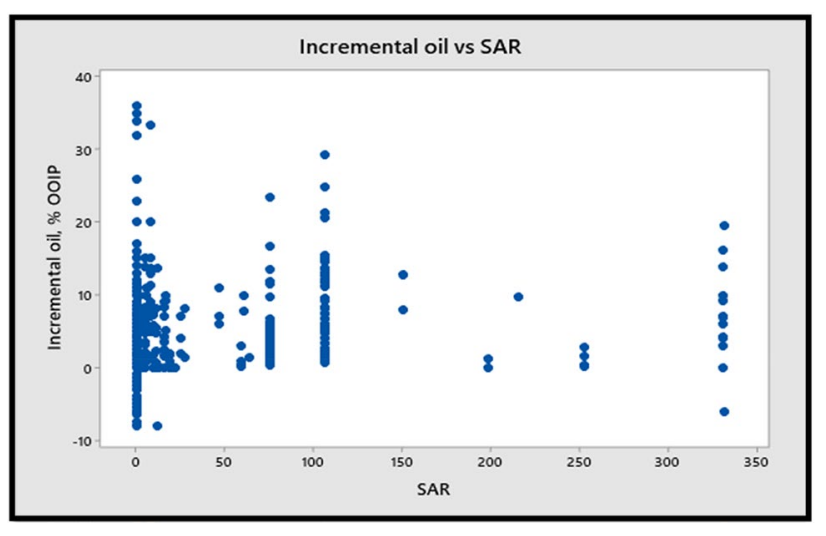

Fig. 4 Relation between sodium adsorption ratio (SAR) and additional oil recovery

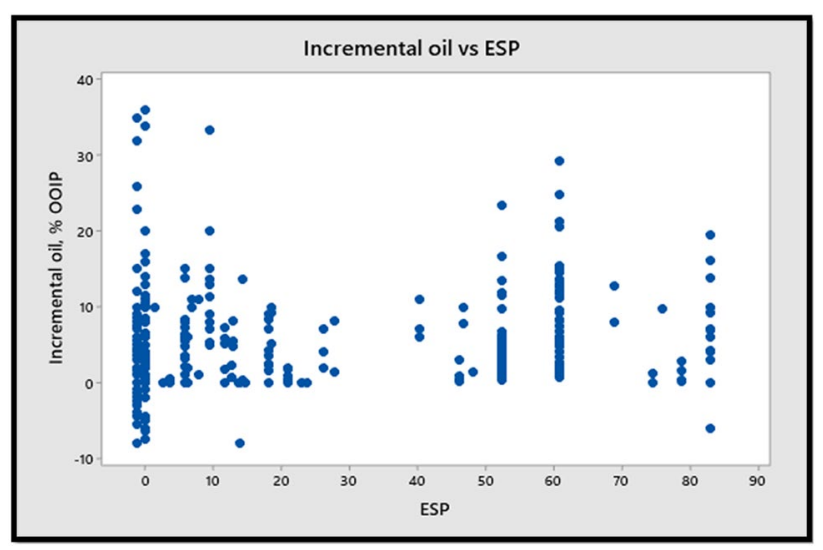

Fig. 5 Relation between the exchangeable sodium percentage (ESP) and additional oil recovery

Exchangeable sodium percentage (ESP) can be calculated from this correlation:

$$
\begin{aligned}
\mathrm{ESP}= & 100 *(0.01475 * \mathrm{SAR}-0.0126) / \\
& (1+(0.01475 * \mathrm{SAR}-0.0126))
\end{aligned}
$$

As clay is the role player in LSWF effect, Figs. 4 and 5 show the relation between SAR, and ESP versus incremental oil recovery. There is no consistent relation that can be extracted from the figures.

In addition, the relation between $\mathrm{Ca}^{+2} / \mathrm{Na}^{+}$ratio and incremental oil recovery is shown in Fig. 6. The figure reveals the more incremental oil recovery when the ratio $\mathrm{Ca}^{+2} / \mathrm{Na}^{+}$is less than 0.04 .

Furthermore, Nasralla and Nasr-El-Din (2011) reported that reducing the original $\mathrm{pH}$ from 7.3 to 4.8 resulted in changing the interfaces from high negatively charged to weak negatively charged for both the oil/brine and rock/brine and hence a reduction in oil recovery. This means that there 


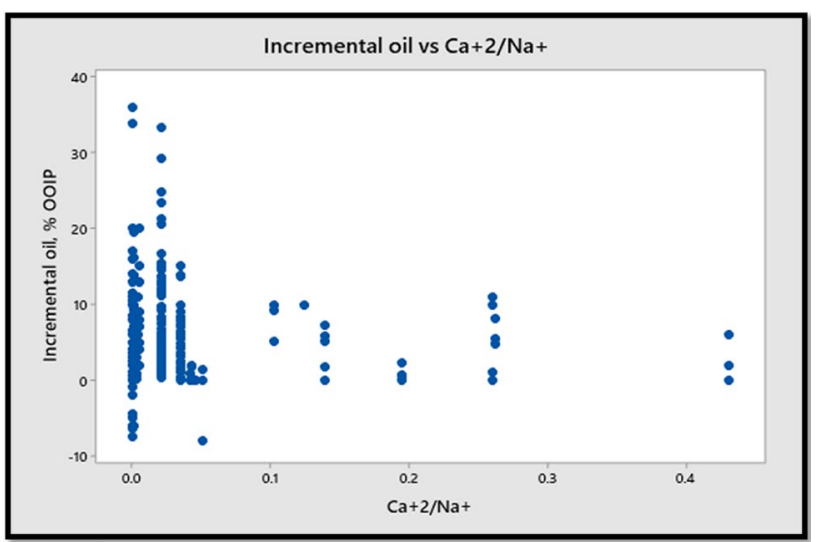

Fig. 6 Relation between $\mathrm{Ca}^{+2} / \mathrm{Na}^{+}$and additional oil recovery

is an optimum $\mathrm{pH}$ as well. They suggested that lowering the $\mathrm{pH}$ of the low-salinity brine changed the electric charges at both oil/brine and rock/brine interfaces from highly negative to closer to neutral. That decreases the repulsive forces and reduces the expansion of the electric double layer caused by low-salinity water. As a result, the rock becomes more oilwet and oil recovery is suppressed compared to low-salinity waterflooding at the original $\mathrm{pH}$ of the brines. Brady et al. (2015) predicted that the low-salinity effect is strongest in $\mathrm{pH}$ range between 5 and 6 in which salinity reduction converts the oil/kaolinite edge interaction to repulsive. Furthermore, they showed that the interaction turned into highly repulsive for $\mathrm{pH}$ range between 6 and 9 at all salinities which reduces the LSWF effect. They performed their experiments using oil with acid number/base number around 0.5. However, Chen et al. (2018) and Brady et al. (2015) clarified that the ranges of the $\mathrm{pH}$ that affect repulsive forces depend on oil acid number/base number, and salt concentrations.

\section{Effect of clays content and clay type}

Jerauld et al. (2006), Austad et al. (2010), Robertson et al. (2003), and Seccombe et al. (2008) state that the clay content and clay type are essential parameters in LSWF projects. Amirian et al. (2019) showed that the clay minerals, especially kaolinite, are the controlling factors of improved recovery from LSWF. However, Soraya et al. 2009 concluded that the kaolinite is not necessary for LSWF effect. Shehata and Nasr-El-Din (2014) concluded that although expansion of double layer (EDL) due to kaolinite content might be an important factor, the presence of clay was not necessarily the primary mechanism in LSWF experiments. Bartels et al. (2017) revealed an effect of LSWF by measuring contact angle despite the absence of clay.

Figure $2 b$ reveals the incremental oil recovery versus clay content in the tertiary stage. The highest incremental oil recovery was recorded with the plugs which have less than $5 \mathrm{wt} \%$ clay content. Minor incremental oil recovery (up to $6 \%$ ) was observed with the plugs which have clay content of more than $10 \%$.

Figure $3 \mathrm{~b}$ shows the incremental oil recovery versus clay content in secondary stage. Few plugs had a description for clay content. The highest incremental oil recovery (up to $20 \%$ ) was recorded for the plugs with less than $13 \mathrm{wt} \%$ clay content.

Figures $2 \mathrm{c}$ and $3 \mathrm{c}$ show the relation between the kaolinite content and the additional oil recovery in tertiary and secondary stages. Similar to clay content, there is no direct relation between the kaolinite content and the additional oil recovery. Moreover, Rezaeidoust et al. (2010) and Nasralla and Nasr-El-Din (2011) did not notice additional oil recovery in plugs with $3-5 \%$ kaolinite content.

Figure $2 \mathrm{c}$ reveals the incremental oil recovery versus kaolinite content in the tertiary stage. The highest incremental oil recovery was recorded with the plugs which have kaolinite content of less than $2 \mathrm{wt} \%$. Two free kaolinite plugs showed incremental oil recovery up to $8 \%$. Minor incremental oil recovery (up to $3 \%$ ) was observed with the plugs which have kaolinite of more than $6 \mathrm{wt} \%$.

Figure $3 \mathrm{c}$ illustrates the incremental oil recovery versus kaolinite content in the secondary stage. Few plugs had a description for kaolinite content in the secondary stage. The achieved incremental recovery during the secondary stage is less sensitive to the kaolinite content less than $5 \mathrm{wt} \%$.

The reviewed literature reported LSWF effect for core plugs containing other types of clay. The presence of reactive plagioclase, such as albite, that can contribute to increasing the $\mathrm{pH}$ was shown by Piñerez et al. (2016) to increase recovery. Siyambalagoda and Thyne (2011) showed additional oil recovery in the presence of calcite without any other type of clay. Cissokho et al. (2010) reported a $10 \%$ increase in recovery by injecting low-salinity brine into sandstone cores that contained illite and chlorite and were free from kaolinite.

\section{Effect of permeability}

The literature review did not show direct relation between permeability and LSWF as shown in Figs. $2 d$ and 3d. Additional oil recovery was noticed in all ranges of permeability.

As shown in Fig. 2d, the plugs with a range of 100-1000 $\mathrm{mD}$ permeability showed the highest incremental oil recovery in the tertiary stage. The incremental oil recovery was less than $10 \%$ for plugs with permeability less than $5 \mathrm{mD}$. Figure $3 \mathrm{~d}$ shows that plugs with approximately $100 \mathrm{mD}$ permeability gave the highest incremental oil recovery in the secondary stage, while incremental oil recovery was less than $5 \%$ for plugs with permeability less than $10 \mathrm{mD}$.

Shaker and Skauge (2012) and Hadia et al. (2012) showed that a low-salinity flood seemed favorable when the initial

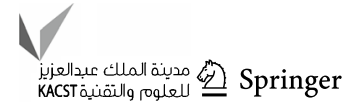


wetting conditions were not water wet. Ashraf et al. (2010) found a higher reduction in residual oil saturation under water-wet conditions.

\section{Effect of temperature}

Rezaeidoust et al. (2010) did not show any additional oil recovery for experiments conducted at temperatures below $140{ }^{\circ} \mathrm{F}$ in the tertiary stage. Nasralla et al. (2011) did not notice any additional oil recovery in experiments conducted at temperature above $212^{\circ} \mathrm{F}$ in the tertiary stage.

Aghaeifar et al. (2015) observed that the LS EOR effect decreases as the reservoir temperature increases due to the decrease in the adsorption of the active organic polar components onto clay minerals. Piñerez et al. (2016) revealed that there is small induction in $\mathrm{pH}$ gradient, when the reservoir temperature is increased (especially when Tres $>212{ }^{\circ} \mathrm{F}$ ) which decreases the effect of LSWF. However, Arumugam et al. (2019) claim a high-temperature sandstone reservoir will be a potential candidate for LSWF.

\section{Fractional factorial design analysis}

Fractional factorial design (FFD) is a commonly used method of experimental design which can be used to enhance and simplify the studies. Two-level folded Plackett-Burman design was used to estimate the high effective factors on the incremental oil recovery.
The analysis was carried out using rock, clay, formation fluid, HS, and LS properties. Some of the literature data had the complete set of all parameters, while others did not have the clay properties. As a result of that, the analysis was performed using all the dataset and repeated again using the data without clay properties. Furthermore, the analysis was performed for both secondary and tertiary stages combined and repeated for secondary and tertiary stages individually. Accordingly, six analyses were performed to identify the parameters which have the most influence on the LSWF incremental oil recovery.

The first analysis was carried out using all datasets which include clay properties data in both secondary and tertiary stages. These datasets were not large enough due to the small amount of experiments with clay description. The second analysis was carried out using all datasets without considering clay properties as a regression parameter. Figure 7 shows that the most dominant parameters in the LSWF are the minerals of the injected low-salinity water $\left(\mathrm{Mg}^{+2}, \mathrm{Na}^{+}\right.$, and $\mathrm{Ca}^{+2}$ and $\mathrm{Ca}^{+2}$ of the formation water). However, Fig. 8 clarifies that in the absence of taking clay content in consideration, the high-salinity minerals are the major parameters in the LSWF.

Figures 9 and 10 show the results of the analysis for the application of the LSWF in the secondary stage with and without the clay content, respectively. The figures reveal the same results: Without considering the clay properties in the regression, the high-salinity minerals are the most effective parameters in the LSWF. In addition, the results of

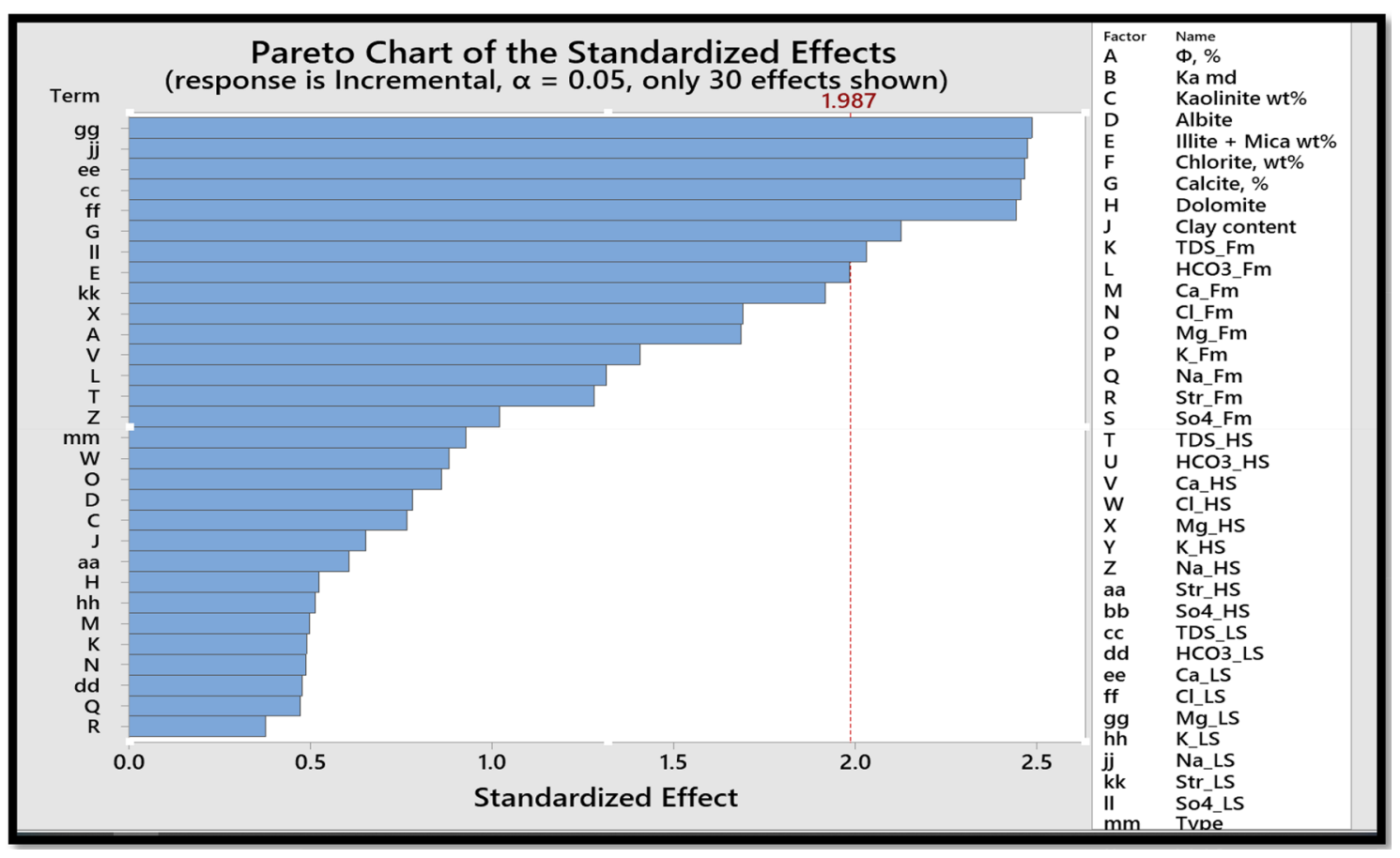

Fig. 7 Pareto chart using the complete dataset of the secondary and tertiary stages 


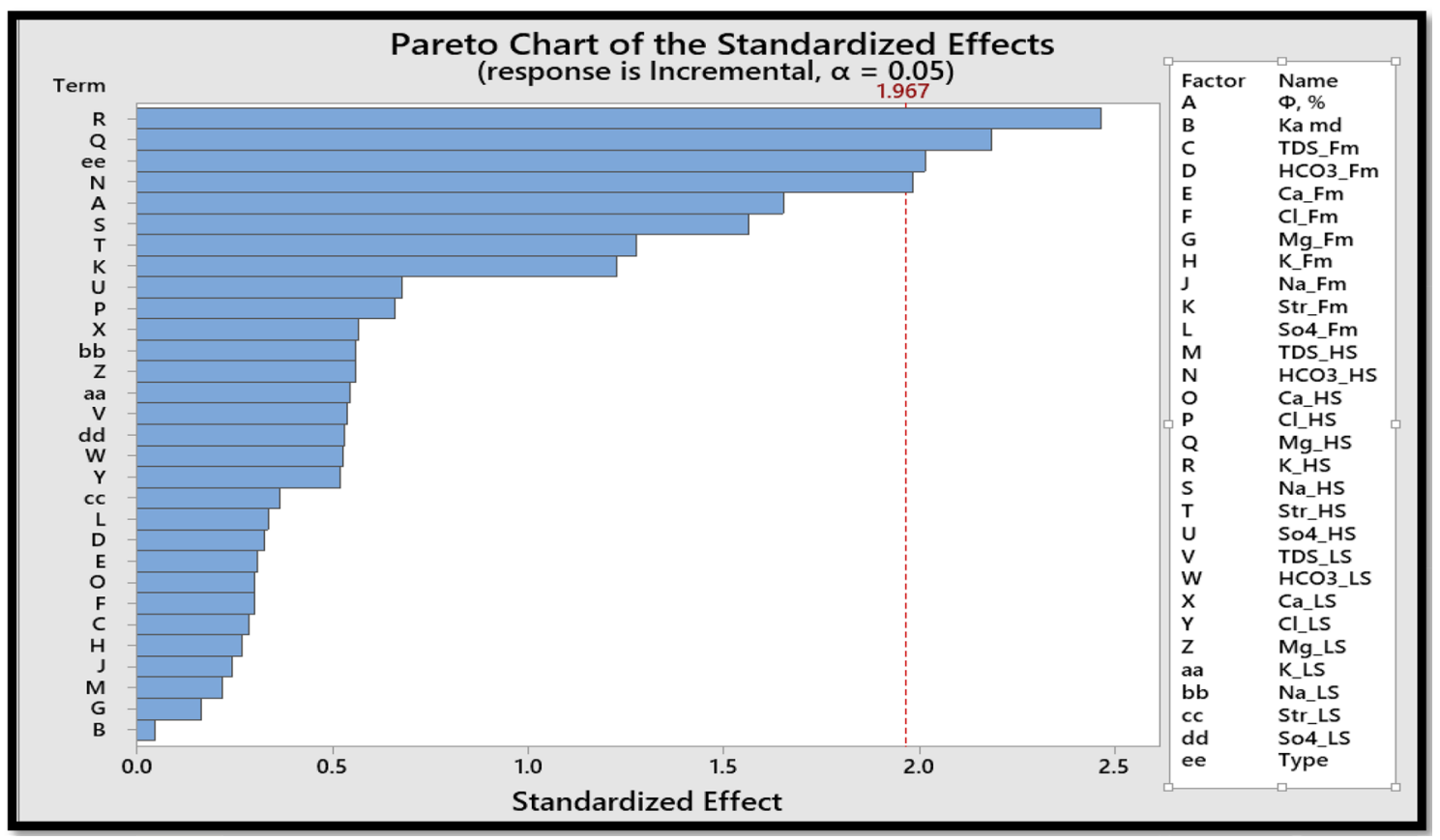

Fig. 8 Pareto chart using the datasets (without considering clay properties) of the secondary and tertiary stages

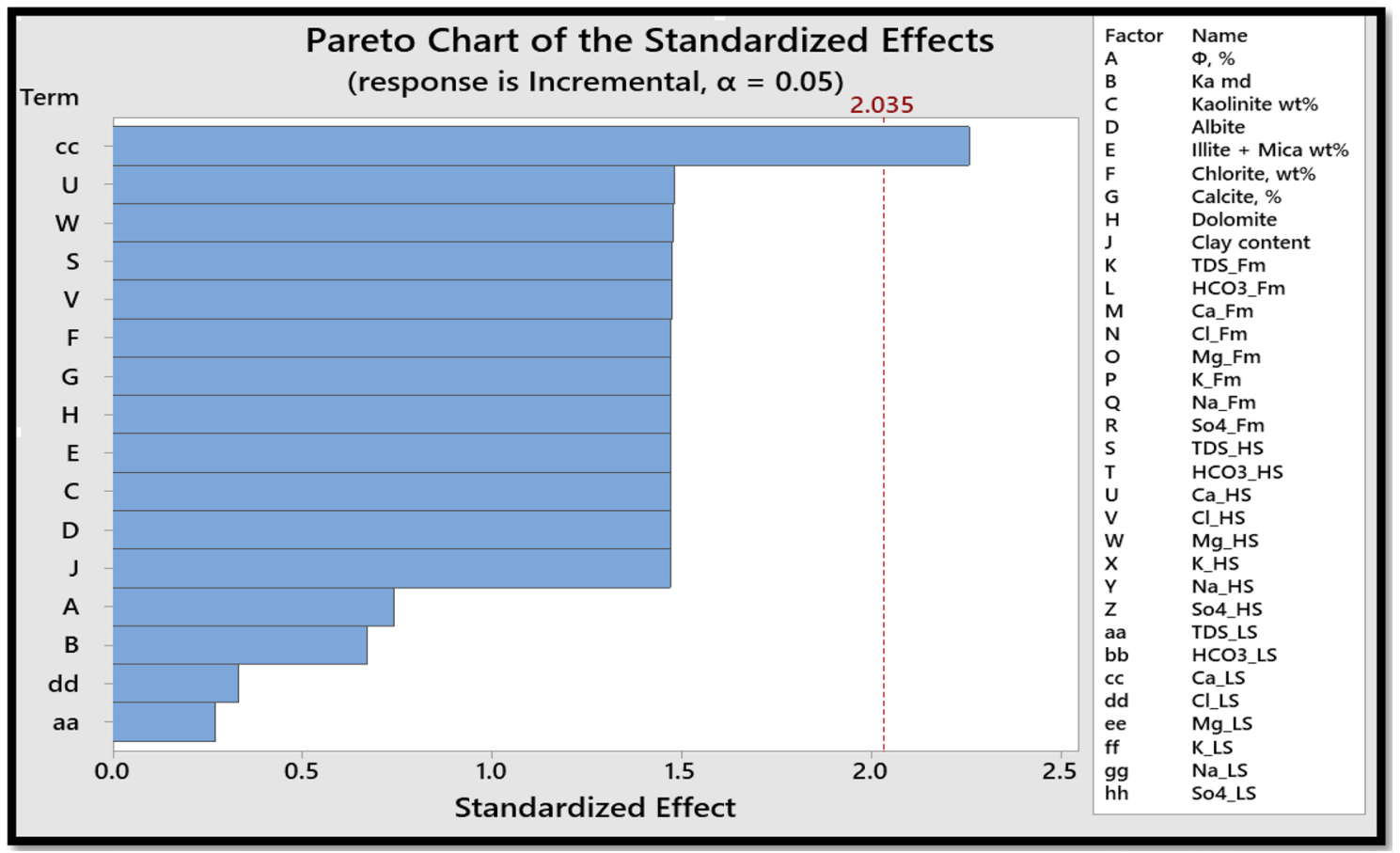

Fig. 9 Pareto chart using the complete dataset of the secondary stage

the analysis showed that the low-salinity minerals, especially $\mathrm{Ca}^{+2}$, are the major parameters in the LSWF when taking clay properties in consideration.
These results match with those obtained by Lager et al. (2008a), Austad et al. (2010), Haagh et al. (2017), and others who showed that the salt content of the injected water 


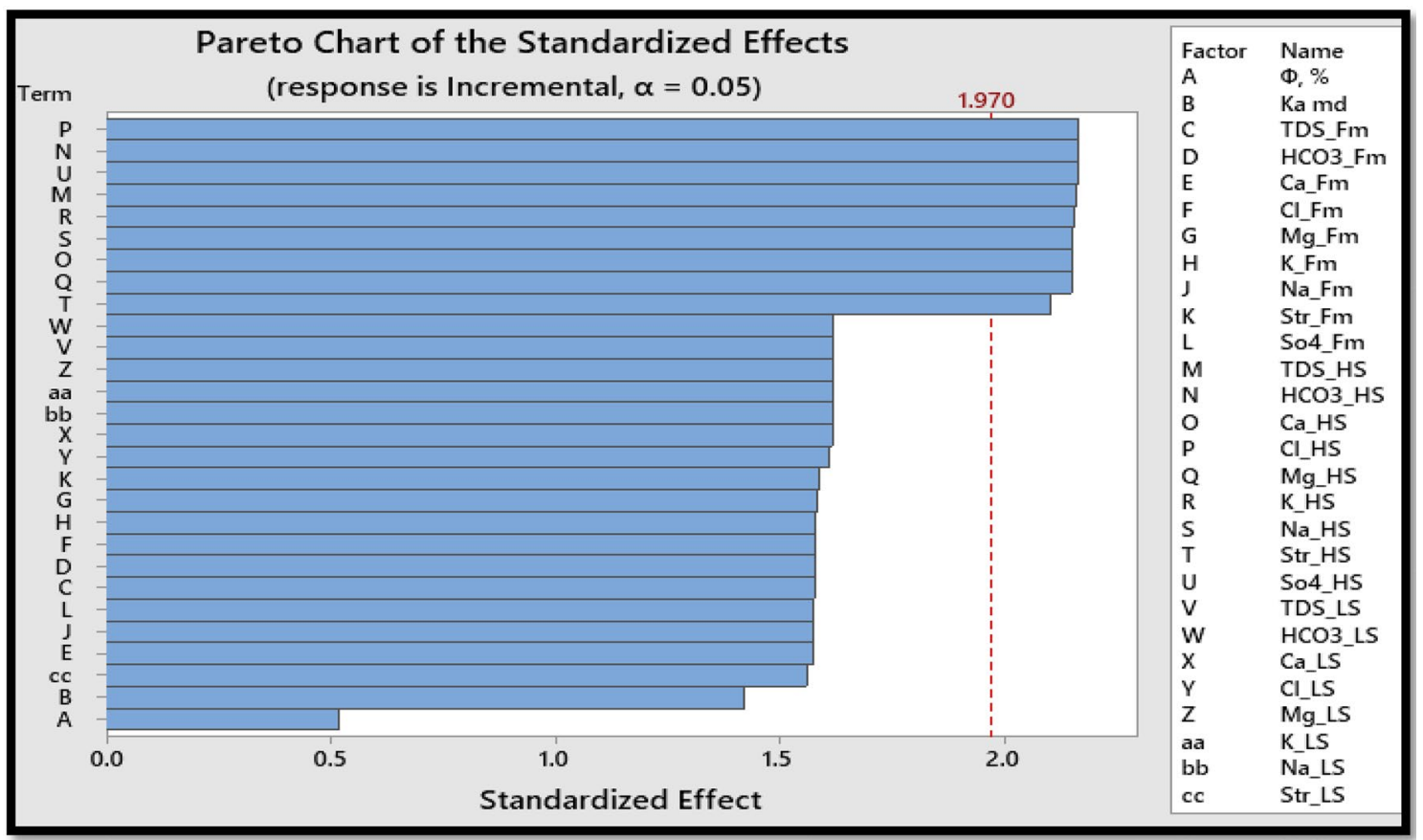

Fig. 10 Pareto chart using the datasets (without considering clay properties) of the secondary stage

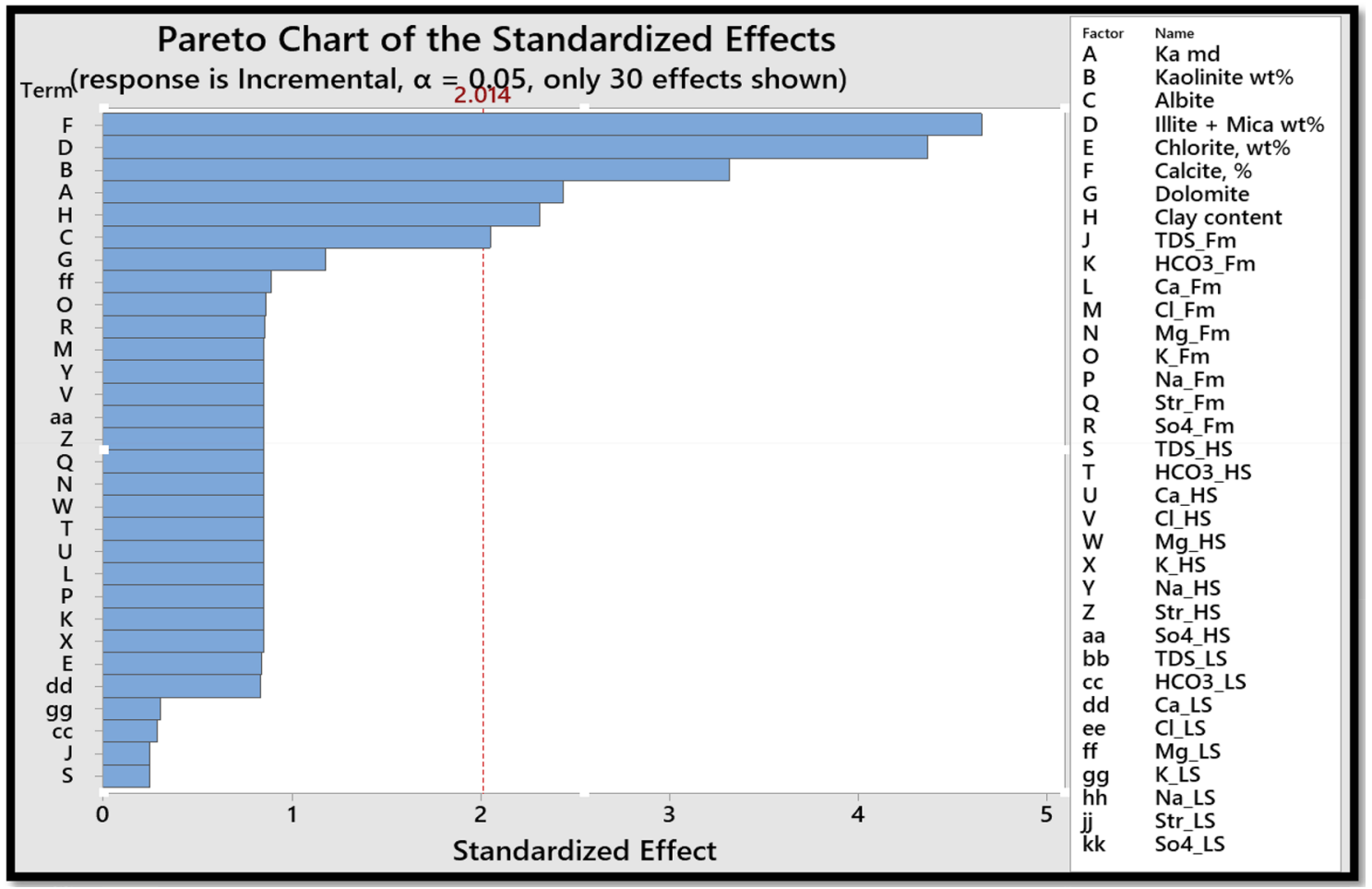

Fig. 11 Pareto chart using the complete dataset of the tertiary stage 


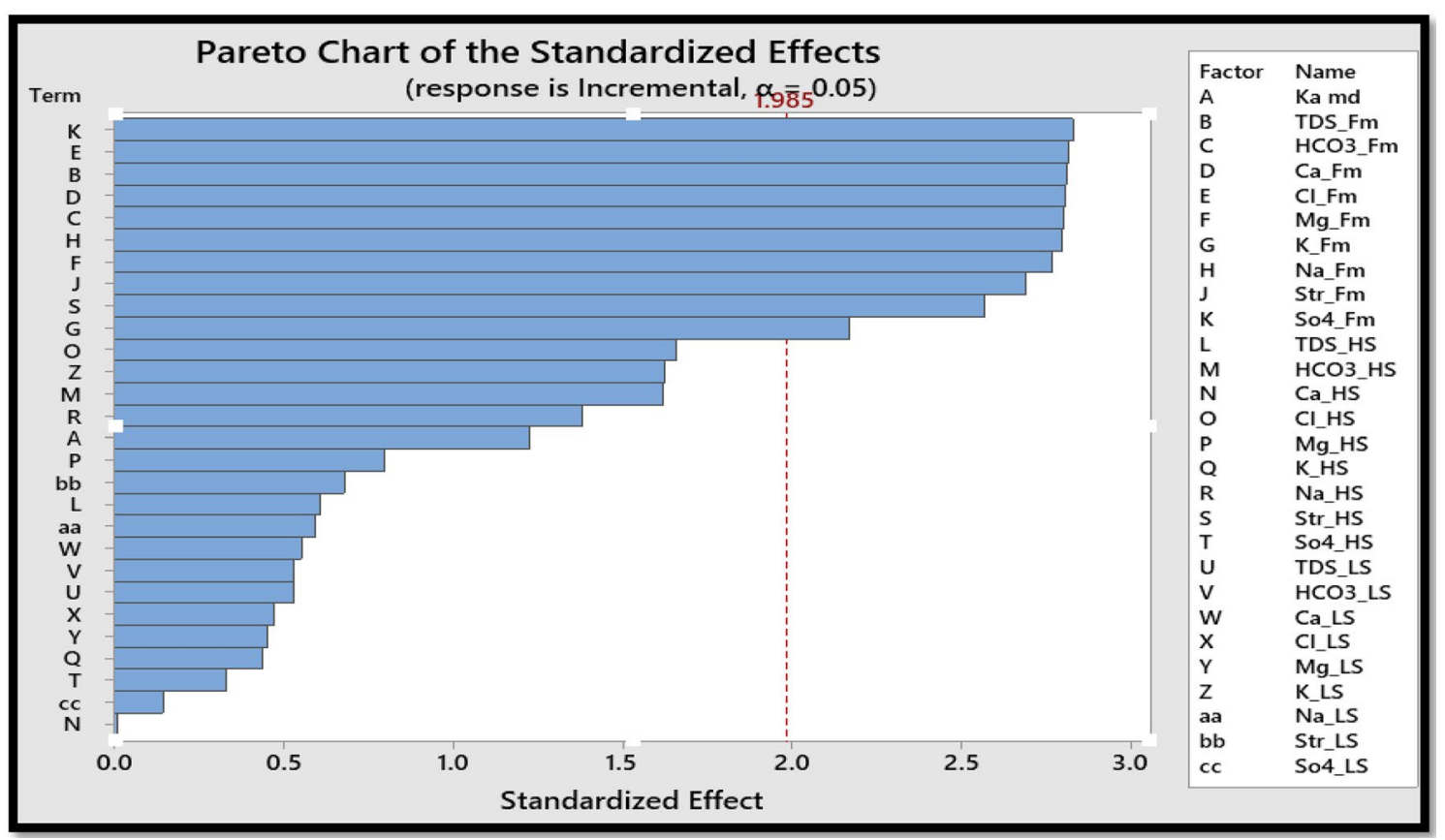

Fig. 12 Pareto chart using the datasets (without considering clay properties) of the tertiary stage

and the concentrations of the divalent ions have a strong effect on the wettability.

Furthermore, Figs. 11 and 12 present the analysis results which determine the most effective parameters when the LSWF is applied in the tertiary flooding stage. The results show that the clay content, clay minerals, and formation fluid properties are the most dominant parameters, when the LSWF is applied in the tertiary stage.

\section{Screening criteria}

Aghaeifar et al. (2015) require a balanced adsorption of organic material, $\mathrm{Ca}^{2+}$ and $\mathrm{H}^{+}$onto the clay surfaces to notice the effect of LSWF. This can be obtained if: (1) the rock contains a significant amount of active clays (illite and kaolinite), preferentially more than $10 \%$ in weight; (2) the crude oil contains polar components, acidic, and/or basic material, quantified by the acid number (AN) and base number (BN); (3) the formation water contains divalent cations, especially $\mathrm{Ca}^{2+}$; or (4) the initial reservoir $\mathrm{pH}$ is less than $6.5(\mathrm{pH}<6.5)$.

Rotondi et al. (2014) documented the following criteria for best results when applying LSWF: (1) The injected source water should have a salinity less than $6000 \mathrm{ppm}$ with optimal range between 1000 and 2000 ppm; (2) the formation rock should contain water sensitive minerals (clay) and should not be strongly water wet; (3) the formation brine should contain divalent ions; and (4) the reservoir oil should contain polar components.
However, by reviewing the literature, some elements of the screening criteria are validated and accepted, while others should be added and/or modified. The comprehensive review of the literature results allows the recognition of different screening criteria for LSWF in secondary and tertiary stages.

For the tertiary stage waterflooding, changing the salinity can give additional oil recovery. In addition, the reservoir temperature should be between 140 and $212^{\circ} \mathrm{F}$.

For the secondary stage waterflooding, there is an optimum salinity between the conventional high salinity (formation water) and the salinity of the freshwater. In addition, the optimum injected water should have the same $\mathrm{pH}$ of the formation water with best results when $\mathrm{pH}$ is around 5-6. The reservoir temperature should be above $140{ }^{\circ} \mathrm{F}$ (with no maximum limit for the temperature).

In both secondary and tertiary stages, there must be the presence of at least of one of the following: kaolinite, illite, chlorite, albite, or calcite to notice additional oil recovery. The injected water monovalent cations should be higher than the divalent cations. In addition, the permeability should be higher than $2 \mathrm{md}$.

\section{Conclusions}

In this work, a comprehensive literature review was conducted and data from the literature were analyzed to derive new findings and screening criteria for low-salinity water 
injection. Based on the results of this study, the following conclusions can be made:

- There is an optimum salinity, optimum injected water composition, and optimum $\mathrm{pH}$ for waterflooding each reservoir rock. Careful design of water injection (when cost allows) will improve displacement efficiency and yield additional recovery.

- Clean sand reservoirs without clay content and with good permeability are expected to give less oil recovery during low-salinity waterflooding projects than high-salinity waterflooding.

- Experimental work for each specific reservoir is essential for determining the optimum salinity.

- Changing the water salinity (not LS) in the tertiary stage of EOR waterflooding gives additional recovery.

- Best results for the secondary stage of LSWF (screening criteria) will be obtained when:

- The presence of kaolinite, albite, and/or calcite.

- Permeability should be higher than $2 \mathrm{md}$.

- Monovalent cations in the injected water should be higher than divalent cations.

- Temperature should be higher than $140^{\circ} \mathrm{F}$.

- $\mathrm{Ca}^{+2} / \mathrm{Na}^{+}$ratio should be less than 0.04 . Some screening criteria for tertiary stage of EOR waterflooding are:

- The presence of kaolinite, albite, and/or calcite.

- Permeability should be more than $2 \mathrm{md}$.

- Monovalent cations in the injected water should be higher than divalent cations.

- Temperature should be higher than $140{ }^{\circ} \mathrm{F}$ and less than $212^{\circ} \mathrm{F}$.

Open Access This article is licensed under a Creative Commons Attribution 4.0 International License, which permits use, sharing, adaptation, distribution and reproduction in any medium or format, as long as you give appropriate credit to the original author(s) and the source, provide a link to the Creative Commons licence, and indicate if changes were made. The images or other third party material in this article are included in the article's Creative Commons licence, unless indicated otherwise in a credit line to the material. If material is not included in the article's Creative Commons licence and your intended use is not permitted by statutory regulation or exceeds the permitted use, you will need to obtain permission directly from the copyright holder. To view a copy of this licence, visit http://creativecommons.org/licenses/by/4.0/.

\section{References}

Agbalaka CC, Dandekar AY, Patil SL, Khataniar S, Hemsath J (2008) The effect of wettability on oil recovery: a review. Society of Petroleum Engineers. https://doi.org/10.2118/114496-MS
Aghaeifar Z, Strand S, Austad T, Puntervold T, Aksulu H, Navratil K et al (2015) Influence of formation water salinity/composition on the low-salinity enhanced oil recovery effect in high-temperature sandstone reservoirs. Energy Fuels 29(8):4747-4754

Alagic E, Skauge A (2010) Combined low salinity brine injection and surfactant flooding in mixed-wet sandstone cores. Energy Fuels 24(6):3551-3559

Alotaibi MB, Azmy RM, Nasr-El-Din AH (2010) Wettability studies using low-salinity water in sandstone reservoirs. In: Offshore technology conference. Houston, Texas, USA. https://doi. org/10.4043/20718-MS

AlQuraishi AA, AlHussinan SN, AlYami HQ (2015) Efficiency and recovery mechanisms of low salinity water flooding in sandstone and carbonate reservoirs. In: Offshore Mediterranean conference

Amirian T, Haghighi M, Mostaghimi P (2017) Pore scale visualization of low salinity water flooding as an enhanced oil recovery method. Energy Fuels 31(12):13133-13143

Amirian T, Haghighi M, Sun C, Armstrong RT, Mostaghimi P (2019) Geochemical modelling and microfluidic experiments to analyse impact of clay type and cations on low salinity water flooding. Energy Fuels

Arumugam S, Mahmud HB, Tan T, Giwelli A, Tan A (2019) A numerical investigation of low-salinity waterflooding capability to enhanced oil recovery. In: IOP conference series: materials science and engineering (vol 495, no 1). IOP Publishing

Ashraf A, Hadia N, Torsaeter O, Tweheyo MT (2010) Laboratory investigation of low salinity waterflooding as secondary recovery process: effect of wettability. Society of Petroleum Engineers. https://doi.org/10.2118/129012-MS

Austad T, Rezaeidoust A, Puntervold T (2010) Chemical mechanism of low salinity water flooding in sandstone reservoirs. Society of Petroleum Engineers. https://doi.org/10.2118/129767-MS

Bartels WB, Mahani H, Berg S, Menezes R, van der Hoeven JA, Fadili A (2017) Oil configuration under high-salinity and lowsalinity conditions at pore scale: a parametric investigation by use of a single-channel micromodel. SPE J 22(05):1-362

Bernard G (1967) Effect of floodwater salinity on recovery of oil from cores containing clays. In: Thirty-eight annual California regional meeting of SPE. Los Angeles, California: Society of petroleum engineering. https://doi.org/10.2118/1725-MS

Bourrie G (2014) Swelling clays and salt-affected soils: demixing of $\mathrm{Na} / \mathrm{Ca}$ clays as the rationale for discouraging the use of sodium adsorption ratio (SAR). Eurasian J Soil Sci 3(4):245

Brady PV, Morrow NR, Fogden A, Deniz V, Loahardjo N (2015) Electrostatics and the low salinity effect in sandstone reservoirs. Energy Fuels 29(2):666-677

Buckley JS, Liu Y, Monsterleet S (1998) Mechanisms of wetting alteration by crude oils. Society of Petroleum Engineers. https ://doi.org/10.2118/37230-PA

Callegaro C, Bartosek M, Masserano F, Nobili M, Parracello P, Parasiliti V et al (2013) Opportunity of enhanced oil recovery low salinity water injection: from experimental work to simulation study up to field proposal. In: EAGE annual conference \& exhibition incorporating SPE Europec. Society of Petroleum Engineers

Chavan M, Dandekar A, Patil S, Khataniar S (2019) Low-salinity-based enhanced oil recovery literature review and associated screening criteria. Petrol Sci 1-17

Cissokho M, Bertin H, Boussour S, Cordier P, Hamon G (2010) Low salinity oil recovery on clayey sandstone: experimental study. Society of Petrophysicists and Well-Log Analysts

Facanha JM, Mahzari P, Sohrabi M (2017) Direct observation of lowsalinity water effect: relationship between micro-dispersion formation and wettability alteration. In: SPE Middle East oil \& gas show and conference. Society of Petroleum Engineers 
Farooq U, Asif N, Tweheyo MT, Sjöblom J, Øye G (2011) Effect of low-saline aqueous solutions and $\mathrm{pH}$ on the desorption of crude oil fractions from silica surfaces. Energy Fuels 25(5):2058-2064

Fjelde I, Asen SM, Omekeh AV (2012) Low salinity water flooding experiments and interpretation by simulations. Society of Petroleum Engineers. https://doi.org/10.2118/154142-MS

Fjelde I, Omekeh AV, Sokama-Neuyam YA (2014) Low salinity waterflooding: effect of crude oil composition. In: SPE improved oil recovery symposium. Society of Petroleum Engineers

Fogden A (2011) Effect of water salinity and $\mathrm{pH}$ on the wettability of a model substrate. Energy Fuels 25(11):5113-5125

Fredriksen SB, Rognmo AU, Fernø MA (2016) Pore scale mechanisms during low salinity waterflooding: water diffusion and osmosis for oil mobilization. In: SPE Bergen one day seminar. Society of Petroleum Engineers

Fredriksen SB, Rognmo AU, Sandengen K, Fernø MA (2017) Wettability effects on osmosis as an oil-mobilization mechanism during low-salinity waterflooding. Petrophysics 58(01):28-35

Gamage S, Hasanka P, Thyne GD (2011) Comparison of oil recovery by low salinity waterflooding in secondary and tertiary recovery modes. In: SPE annual technical conference and exhibition. Society of Petroleum Engineers|

Haagh MEJ, Sîretanu I, Duits MHG, Mugele F (2017) Salinity dependent contact angle alteration in oil/brine/silicate systems: the critical role of divalent cations. Langmuir 33(14):3349-3357

Hadia N, Lehne HH, Kumar KG, Selboe KA, Stensen FÅ, Torsater O (2011) Laboratory investigation of low salinity waterflooding on reservoir rock samples from the fry field. Society of Petroleum Engineers. https://doi.org/10.2118/141114-M

Hadia NJ, Hansen T, Tweheyo MT, Torsæter O (2012) Influence of crude oil components on recovery by high and low salinity waterflooding. Energy Fuels 26(7):4328-4335

Hosseinzade KH, Torsæter O, Stensen JA (2016) Effect of calcium in pore scale oil trapping by low-salinity water and surfactant enhanced oil recovery at strongly water-wet conditions: in situ imaging by X-ray microtomography. Energy Fuels 30(10):8114-8124

Jerauld GR, Webb KJ, Lin C-Y, Seccombe J (2006) Modeling lowsalinity waterflooding. Society of Petroleum Engineers. https:// doi.org/10.2118/102239-MS

Kakati A, Jha NK, Kumar G, Sangwai JS (2017) Application of low salinity water flooding for light paraffinic crude oil reservoir. In: SPE symposium: production enhancement and cost optimisation. Society of Petroleum Engineers

Keogh W, Neville A, Huggan M, Eroini V, Olsen JH, Nielsen FM et al (2017) Deposition of inorganic carbonate, sulfate, and sulfide scales on antifouling surfaces in multiphase flow. Energy Fuels 31(11):11838-11851

Lager A, Webb KJ, Black CJJ, Singleton M, Sorbie KS (2008a) Low salinity oil recovery-an experimental investigation. Society of Petrophysicists and Well-Log Analysts

Lager A, Webb KJ, Collins IR, Richmond DM (2008b) LoSal enhanced oil recovery: evidence of enhanced oil recovery at the reservoir scale. Society of Petroleum Engineers. https://doi. org/10.2118/113976-MS

Law S, Sutcliffe PG, Fellows SA (2014) Secondary application of low salinity waterflooding to forties sandstone reservoirs. Society of Petroleum Engineers. https://doi.org/10.2118/170725-MS

Lebedeva EV, Fogden A (2011) Micro-CT and wettability analysis of oil recovery from sand packs and the effect of waterflood salinity and kaolinite. Energy Fuels 25(12):5683-5694

Li M, Vashaee S, Romero-Zerón L, Marica F, Balcom BJ (2017) A magnetic resonance study of low salinity waterflooding for enhanced oil recovery. Energy Fuels 31(10):10802-10811
Ligthelm DJ, Gronsveld J, Hofman J, Brussee N, Marcelis F, van der Linde H (2009) Novel waterflooding strategy by manipulation of injection brine composition. Society of Petroleum Engineers. https://doi.org/10.2118/119835-MS

Lu Y, Najafabadi NF, Firoozabadi A (2017) Effect of temperature on wettability of oil/brine/rock systems. Energy Fuels 31(5):4989-4995

Mamonov A, Puntervold T, Strand S (2017) EOR by smart water flooding in sandstone reservoirs-effect of sandstone mineralogy on initial wetting and oil recovery. In: SPE Russian petroleum technology conference. Society of Petroleum Engineerś

Marhaendrajana T, Ridwan MG, Kamil MI, Permadi P (2018) Wettability alteration induced by surface roughening during low salinity waterflooding. J Eng Technol Sci 50(5):635-649

McGuire PL, Chatham JR, Paskvan FK, Sommer DM, Carini FH (2005) Low salinity oil recovery: an exciting new EOR opportunity for Alaska and Apos;s North Slope. Society of Petroleum Engineers. https://doi.org/10.2118/93903-MS

Mehana M, Al Salman M, Fahes M (2017) The impact of salinity on water dynamics, hydrocarbon recovery and formation softening in Shale: experimental study. In: SPE Kingdom of Saudi Arabia annual technical symposium and exhibition. Society of Petroleum Engineers

Miyauchi TEC, Lu Y, Firoozabadi A (2017) Low salinity water injection: effect of acid and base functionality on recovery performance. In: SPE annual technical conference and exhibition. Society of Petroleum Engineers

Mjøs JES (2014) Low salinity waterflood in combination with surfactant/polymer: effect of brine composition. Master's thesis, The University of Bergen

Mohamed MI, Alvarado V (2017) Smart water flooding in Berea Sandstone at low temperature: Is wettability alteration the Sole mechanism at play? In: SPE annual technical conference and exhibition. Society of Petroleum Engineers

Morrow N, Buckley J (2011) improved oil recovery by low-salinity waterflooding. J Petrol Technol 63(05):106-112

Morrow NR, Tang GQ, Valat M, Xie X (1998) Prospects of improved oil recovery related to wettability and brine composition. J Petrol Sci Eng 20(3-4):267-276

Mugele F, Siretanu I, Kumar N, Bera B, Wang L, de Ruiter R et al (2016) Insights from ion adsorption and contact-angle alteration at mineral surfaces for low-salinity waterflooding. SPE J 21(04):1-204

Nasralla RA, Nasr-El-Din HA (2011) Impact of electrical surface charges and cation exchange on oil recovery by low salinity water. Society of Petroleum Engineers. https://doi.org/10.2118/14793 7-MS

Nasralla RA, Nasr-El-Din HA (2012) Double-layer expansion: Is it a primary mechanism of improved oil recovery by low-salinity waterflooding? Society of Petroleum Engineers. https://doi. org/10.2118/154334-MS

Nasralla RA, Nasr-El-Din HA (2014) Double-layer expansion: Is it a primary mechanism of improved oil recovery by low-salinity waterflooding? SPE Reserv Eval Eng 17(01):49-59

Nasralla RA, Alotaibi MB, Nasr-El-Din HA (2011) Efficiency of oil recovery by low salinity water flooding in sandstone reservoirs. Society of Petroleum Engineers. https://doi.org/10.2118/14460 2-MS

Navrátil KC (2012) An experimental study of low salinity EOR effects on a core from the Yme field. Master's thesis, University of Stavanger, Norway

Patil SB, Dandekar AY, Patil S, Khataniar S (2008) Low salinity brine injection for EOR on Alaska North Slope (ANS). In: International

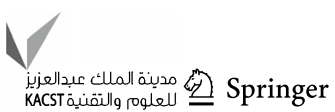


petroleum technology conference. https://doi.org/10.2523/IPTC12004-MS

Piñerez TID, Puntervold T, Strand S, Austad T, Abdullah HI, Olsen K (2016) Experimental study of the response time of the low-salinity enhanced oil recovery effect during secondary and tertiary lowsalinity waterflooding. Energy Fuels 30(6):4733-4739

$\mathrm{Pu}$ H, Xie X, Yin P, Morrow NR (2008) Application of coalbed methane water to oil recovery from Tensleep Sandstone by low salinity waterflooding. Society of Petroleum Engineers. https://doi. org/10.2118/113410-MS

Pu H, Xie X, Yin P, Morrow NR (2010) Low-salinity waterflooding and mineral dissolution. Society of Petroleum Engineers. https:// doi.org/10.2118/134042-MS

Ramanathan R, Shehata AM, Nasr-El-Din HA (2015) Water alternating $\mathrm{CO}_{2}$ injection process-Does modifying the salinity of injected brine improve oil recovery? In: Offshore technology conference. https://doi.org/10.4043/26253-MS

Rezaeidoust A, Puntervold T, Strand S, Austad T (2009) Smart water as wettability modifier in carbonate and sandstone: a discussion of similarities/differences in the chemical mechanisms. Energy Fuels 23(9):4479-4485

Rezaeidoust A, Puntervold T, Austad T (2010) A discussion of the lowsalinity EOR potential for a North Sea sandstone field. Society of Petroleum Engineers. https://doi.org/10.2118/134459-MS

Rivet S, Lake LW, Pope GA (2010) A coreflood investigation of lowsalinity enhanced oil recovery. Society of Petroleum Engineers. https://doi.org/10.2118/134297-MS

Robertson EP (2007) Low-salinity waterflooding to improve oil recovery-historical field evidence. Society of Petroleum Engineers. https://doi.org/10.2118/109965-MS

Robertson EP, Thomas CP, Zhang Y, Morrow NR (2003) Improved waterflooding through injection brine modification. Idaho National Laboratory Report INEEL/EXT-02-01591, DOE Contract DE-AC07-99ID13727

Rotondi M, Callegaro C, Masserano F, Bartosek M (2014) Low salinity water injection: Eni's experience. Society of Petroleum Engineers. https://doi.org/10.2118/171794-MS

Sandengen K, Arntzen OJ (2013) Osmosis during low salinity water flooding. In: IOR 2013-17th European symposium on improved oil recovery (pp. cp-342). European Association of Geoscientists \& Engineers

Sandengen K, Tweheyo MT, Raphaug M, Kjølhamar A, Crescente C, Kippe V (2011) Experimental evidence of low salinity water flooding yielding a more oil-wet behaviour. In: Proceedings of the international symposium of the Society of Core Analysts (pp $18-21)$

Sandengen K, Kristoffersen A, Melhuus K, Jøsang LO (2016) Osmosis as mechanism for low-salinity enhanced oil recovery. SPE J 21(04): 1-227

Seccombe JC, Lager A, Webb KJ, Jerauld G, Fueg E (2008) Improving waterflood recovery: LoSalTM EOR field evaluation. Society of Petroleum Engineers. https://doi.org/10.2118/113480-MS

Shabaninejad M, Middleton J, Latham S, Fogden A (2017) Pore-scale analysis of residual oil in a reservoir sandstone and its dependence on water flood salinity, oil composition, and local mineralogy. Energy Fuels 31(12):13221-13232

Shaker B, Skauge A (2012) Wettability and oil recovery by low salinity injection. Society of Petroleum Engineers. https://doi. org/10.2118/155651-MS

Shaker SB, Skauge A (2013) Enhanced oil recovery (EOR) by combined low salinity water/polymer flooding. Energy Fuels 27(3):1223-1235

Shehata AM, Nasr-El-Din HA (2014) Role of sandstone mineral compositions and rock quality on the performance of low-salinity waterflooding. In: International petroleum technology conference. https://doi.org/10.2523/IPTC-18176-MS
Shehata AM, Nasr-El-Din HA (2015) Zeta potential measurements: impact of salinity on sandstone minerals. In: SPE international symposium on oilfield chemistry. Society of Petroleum Engineers

Shehata AM, Nasr-El-Din HA (2017) The role of sandstone mineralogy and rock quality in the performance of low-salinity waterflooding. SPE Reserv Eval Eng 20(01):87-106

Siyambalagoda GPH, Thyne GD (2011) Comparison of oil recovery by low salinity waterflooding in secondary and tertiary recovery modes. Society of Petroleum Engineers. https://doi. org/10.2118/147375-MS

Skauge A, Fallah S, McKay E (2008) Modeling of LPS linked polymer solutions. In: The 29th IEA workshop and symposium (pp 3-5)

Soraya B, Malick C, Philippe C, Bertin HJ, Hamon G (2009) Oil recovery by low-salinity brine injection: laboratory results on outcrop and reservoir cores. Society of Petroleum Engineers. https://doi. org/10.2118/124277-MS

Sorop TG, Suijkerbuijk BM, Masalmeh SK, Looijer MT, Parker AR, Dindoruk DM et al (2013) Integrated approach in deploying low salinity waterflooding. In: SPE enhanced oil recovery conference. Society of Petroleum Engineers

Sposito G (1989) The chemistry of soils. Oxford University Press, New York

Tang GQ, Morrow NR (1997). Salinity, temperature, oil composition, and oil. In: SPE annual technical conference. Denver, Colorado: Society of petroleum engineering. https://doi.org/10.2118/36680 -MS

Tang GQ, Morrow NR (1999) Influence of brine composition and fines migration on crude oil/brine/rock interactions and oil recovery. $\mathrm{J}$ Petrol Sci Eng 24(2-4):99-111

Tchistiakov AA (2000) Colloid chemistry of in-situ clay-induced formation damage. Society of Petroleum Engineers. https://doi. org/10.2118/58747-MS

Vledder P, Gonalez I, Carrera F, Wells T, Lighhelm D (2010) Low salinity water flooding. Tulsa, Oklahoma: Society of Petroleum Engineering. https://doi.org/10.2118/12956-MS

Webb K, Black C, Al-Ajeel H (2004) Low salinity oil recovery-loginject-log. In: SPE/DOE symposium on improved oil recovery. Tulsa, Oklahoma: Society of Petroleum Engineering. https://doi. org/10.2118/89379-MS

Wei B, Wu R, Lu L, Ning X, Xu X, Wood C, Yang Y (2017) Influence of individual ions on oil/brine/rock interfacial interactions and oil-water flow behaviors in porous media. Energy Fuels 31(11):12035-12045

Zeinijahromi A, Bedrikovetsky P (2013) Physics mechanisms of enhanced recovery by fines-migration-assisted waterflooding (Laboratory Study). In: SPE European formation damage conference \& exhibition. Society of Petroleum Engineers

Zeinijahromi A, Ahmetgareev V, Badalyan A, Khisamov R, Bedrikovetsky P (2015) Case study of low salinity water injection in Zichebashskoe field. J Pet Sci Res 4:16-31

Zekri AY, Nasr MS, Al-Arabai ZI (2011) Effect of LoSal on wettability and oil recovery of carbonate and sandstone formation. In: International petroleum technology conference. https://doi. org/10.2523/IPTC-14131-MS

Zekri AY, Nasr M, Al-Arabai Z (2012) Effect of EOR technology on wettability and oil recovery of carbonate and sandstone formation. In: IPTC 2012: international petroleum technology conference (pp cp-280). European Association of Geoscientists \& Engineers

Zhang Y, Xie X, Morrow NR (2007) Waterflood performance by injection of brine with different salinity for reservoir cores. Society of Petroleum Engineers. https://doi.org/10.2118/109849-MS

Publisher's Note Springer Nature remains neutral with regard to jurisdictional claims in published maps and institutional affiliations. 